\title{
Lead Concentration and Isotopic Compositions in the Central Tropical North Pacific Ocean
}

EDWARD A. BOYLE ${ }^{1}$, SHUO JIANG ${ }^{1,2}$, JESSICA FITZSIMMONS $^{3}$, NATHAN LANNING ${ }^{3}$

${ }^{1}$ Department of Earth, Atmospheric and Planetary Sciences, Massachusetts Institute of Technology, E25-619, 77 Mass. Ave. Cambridge MA USA 02139, eaboyle@mit.edu

${ }^{2}$ SKLEC, Eastern China Normal University, Shanghai, China, jiangshuo1020@163.com

${ }^{3}$ Department of Oceanography, Texas A\&M University, College Station, Texas, USA 77843, jessfitz@tamu.edu

One of the key GEOTRACES trace elements, lead $(\mathrm{Pb})$ in the ocean is highly influenced by human activities. During a cruise (GEOTRACES GP15) along a Pacific Meridional Transect $\left(152^{\circ} \mathrm{W}\right)$ in the central Pacific basin in 2018, seawater samples were collected for $\mathrm{Pb}$ concentration $[\mathrm{Pb}]$ and $\mathrm{Pb}$ isotope ratio profiles at stations $18\left(22.5^{\circ} \mathrm{N}\right), 19$ $\left(17.5^{\circ} \mathrm{N}\right), 21\left(11^{\circ} \mathrm{N}\right), 25\left(5^{\circ} \mathrm{N}\right), 35\left(10.5^{\circ} \mathrm{N}\right)$, and $39\left(20^{\circ} \mathrm{S}\right)$. At most stations (except the most southerly ones) $[\mathrm{Pb}]$ increased from the surface to a maximum at $\sim 300 \mathrm{~m}$ (the highest being $67 \mathrm{pmol} / \mathrm{kg}$ for station 18) and then decreased with depth to $1-5 \mathrm{pmol} / \mathrm{kg}$ near the seafloor. The $[\mathrm{Pb}]$ maximum is usually a minimum for ${ }^{206} \mathrm{~Pb} / 207 \mathrm{~Pb},{ }^{208} \mathrm{~Pb} /{ }^{207} \mathrm{~Pb}$, and ${ }^{206} \mathrm{~Pb} / 204 \mathrm{~Pb}$, ranging from ${ }^{206} \mathrm{~Pb} /{ }^{207} \mathrm{~Pb}=1.151$ at southernmost station 39 to 1.162 at station 18 . Below $300 \mathrm{~m}$, ${ }^{206} \mathrm{~Pb} /{ }^{207} \mathrm{~Pb}$ increased towards the bottom (to 1.190 at station 39 and 1.185 at station 18 At stations 18 and $19,{ }^{208} \mathrm{~Pb} /{ }^{207} \mathrm{~Pb}$ shows a decrease below $\sim 4500 \mathrm{~m}$ which we attribute to the flow of eastward flowing Pacific Bottom Water passing through the deep passage south of Horizon Guyot as described by Edmond, Chung, \& Sclater (1971, JGR 76:8089-8096). Comparison of the near-surface GP15 data, from the upper 160m of South Pacific Zonal Transect (GP16), and from the surface waters of the HOT time-series station north of Hawaii shows significant evolution of $\mathrm{Pb}$ isotope ratios in recent decades. 